Volume 1 Issue 2, September 2016: pp. 205-219. Copyright @ LamLaj. Faculty of Law, Lambung Mangkurat University, Banjarmasin, South Kalimantan, Indonesia. ISSN: 2502-3136 | e-ISSN: 2502-3128. Open Access at: http://lamlaj.unlam.ac.id

\title{
Penggunaan Incoterms dalam Perjanjian Perdagangan Internasional (Studi Pada Pt. Insan Bonafide di Banjarmasin)
}

\author{
Adhitya Christanto Henry Dalim \\ Program Magister Kenotariatan Fakultas Hukum Universitas Lambung Mangkurat, Jalan \\ Brigjend H. Hasan Basri Banjarmasin, 70123 Indonesia \\ Telp/Fax: +62 5113307877 E-Mail: adhitdalim@yahoo.com
}

Diterima: 25/7/2016; Revisi: 01/08/2016; Disetujui: 29/09/2016

\begin{abstract}
The aim of this research is to study and analyze the position of International Commercial Terms (Incoterms) as international customary law in international trade agreement as well as to study and analyze the rights and obligations of the exporters and importers in relation with the use of Incoterms in international trade agreement (study at PT. InsanBonafide in Banjarmasin). The benefits expected from the results of this research are as contribution of thoughts in the field of legal studies, especially in connection with international trade law for the businessmen in sector of international trade and for the government in making legislation concerning international trade. The method of this research is normative legal research by studying legal resources (primary, secondary, and tertiary legal resources) which are relevant to the legal issues being studied. The approach used is analytical approach. The results of this research point out that the legal force of Incoterms in international trade agreement derived from customary law and as international customs which has position as law. Incoterms is source of international trade law. However, the legal force of Incoterms as international customary law is not equal to the legal force of International Agreements such as Convention, Treaty, Charter, Agreement, Covenant, Protocol, Fact, etc. So, in practice, the exporters and importers frequently experience that the provisions of the Incoterms which have been agreed by the parties are then violated by one of the parties because the Incoterms are not yet perfectly regulated. Incoterms still raise problems in their application in the field because there are vague norms with regard to the scope and limits of responsibilities of each party, namely, the exporters and importers.
\end{abstract}

Keywords: Incoterms, International Trade Agreement

Abstrak:Tujuan penelitian ini untuk mengetahui dan menganalisis kedudukan incoterms selaku hukum kebiasaan internasional dalan perjanjian perdagangan internasional serta 
untuk mengetahui dan menganalisis hak dan kewajiban pengusaha eksportir dan importir sehubungan dengan penggunaan Incoterms dalam perjanjian perdagangan internasional (Studi pada PT. Insan Bonafide di Banjarmasin). Kegunaan yang di harapakan dari hasil penelitian Sebagai sumbangan pemikiran dalam bidang ilmu hukum khususnya terkait dengan hukum perdagangan internasional, bagi pelaku usaha di bidang perdagangan internasional dan bagi pemerintah dalam membuat peraturan perundang-undangan (legislasi) berkenaan dengan perdagangan internasional. Metode penelitian ini menggunakan jenis penelitian hukum normatif,yaitu penelitian hukum yang dilakukan dengan cara meneliti bahan hukum(bahan hukum primer, bahan hukum sekunder, dan bahan hukum tersier), yang relevan dengan judul yang di angkat penulis. Ada pun tipe penelitianadalah penelitian dengan menitikberatkan permasalahan yang sering timbul berkaitan dengan kekaburan hukum (vage norm) berkenaan dengan makna dan ruang lingkup dari Incoterms tersebut. Pendekatan penelitian menggunakan pendekatan analitis (analytical approach). Menurut hasil dari penelitian tesis ini menunjukan bahwa: Pertama, mengenai kekuatan hukum Incoterms dalam perjanjian perdagangan internasional, Incoterms yang lahir dari hukum kebiasaan dan sebagai suatu kebiasaan internasional yang berkedudukan hukum yang merupakan sumber hukum perdagangan internasional. namun demikian kekuatan hukum Incoterms selaku hukum kebiasaan internasional tidak sama dengan kekuatan hukum dari Perjanjian Internasional seperti Konvensi, Traktat, Piagam, Agreement, Covenant, Protocol, Pacta, dan lain-lain. Kedua, hak dan kewajiban pengusaha eksportir dan importir sehubungan dengan penggunaan Incoterms dalam perjanjian perdagangan internasional khususnya pada PT. Insan Bonafide dengan menggunakan Incoterms yang telah di sepakati oleh kedua belah pihak namun kenyataannya di lapangan cukup sering ketentuan-ketentuan Incoterms yang telah disepakati oleh para pihak kemudian dilanggar oleh salah satu pihak. karena belum adanya pengaturan yang sempurna di Incoterms ini maka dari itu lah Incoterms masih menimbulkan permasalahan dalam aplikasi/penerapannya di lapangan karena masih terdapat kekaburan hukum mengenai ruang lingkup dan batas-batas tanggung jawab masingmasing pihak antara penjual (eksportir) dan importir.

Kata Kunci : Incoterms, Perjanjian Perdagangan Internasional.

\section{PENDAHULUAN}

Dengan adanya perkembangan zaman yang semakin modern, dalam dunia internasional tiap-tiap Negara dituntut secara tidak langsung untuk dapat bersaing dengan Negara lainnya. Untuk dapat bersaing tentu saja suatu Negara harus berusaha untuk meningkatkan pertumbuhan ekonominya dengan cara memperoleh pendapatan yang besar dari setiap kegiatan usaha yang dilakukannya.
Dengan adanya kegiatan usaha antar negara satu dengan negara yang lainnya yang bisa disebut juga dengan perdagangan internasional maka kedua belah pihak antar negara pastilah telah menyepakati suatu hubungan kerja,dari skala kecil antar person dalam negeri sampai skala besar antar negara yang disebut dengan kegiatan ekspor impor.

Dalam kegiatan ekspor maupun impor pastilah terjadi kegiatan pengiriman barang (cargo) dari suatu negara ke negara lain dan 
dalam proses pengiriman tersebut sangat mungkin timbul berbagai persoalan seperti hilang atau rusaknya barang atau bahkan yang paling buruk adalah tidak terlaksananya penyerahan barang. Masalah pengiriman barang juga penting karena menyangkut beberapa hal seperti siapa yang berkewajiban membayar ongkos angkut, biaya penimbunan, biaya asuransi, siapa yang menanggung risiko hilang dan rusaknya serta kapan risiko tersebut beralih dari eksportir kepada importir. Untuk menjamin hak dan kewajiban semua pihak yang terlibat maka perlu ada kontrak perdagangan yang memberi kepastian tentang hak, kewajiban dan tanggung jawab mereka masing-masing. ${ }^{1}$

Seringkali para pihak dalam suatu perjanjian perdagangan internasional tidak menyadari adanya praktik-praktik perdagangan yang berbeda antara negaranya dengan negara lain. dalam Perdagangan Internasional tersebut melibatkan beberapa subjek hukum atau para pihak yang mempunyai hukum Nasional yang berbeda. Hal ini dapat menimbulkan salah paham, atau bahkan sengketa yang hanya akan menghamburkan waktu dan biaya yang tidak sedikit. Untuk mencegah hal buruk demikian itu, maka Kamar Dagang Internasional (International Chamber of Commerce-ICC) berupaya mengurangi perbedaan penafsiran terhadap syarat-syarat perdagangan internasional tersebut.

International Chamber of Commerce atau ICC yang berpusat di Paris merupakan sebuah organisasi nirlaba internasional yang bekerja mempromosikan dan mendukung perdagangan global dan globalisasi. Berperan

1 Gunawan Widjaja \& Ahmad Yani. 2001. Transaksi Bisnis Internasional (Ekspor-Impor \& Imbal Beli. Seri Hukum Bisnis. Jakarta: Rajawali Pers. hlm 139 sebagai perwakilan sejumlah bisnis dunia dalam ekonomi global, terhadap pertumbuhan ekonomi, pembuatan lowongan kerja, dan kemakmuran. Sebagai sebuah organisasi bisnis global, terdiri dari negara anggota, badan ini membantu pembangunanglobal pada masalah bisnis. ICC memiliki akses langsung ke pemerintah nasional di seluruh dunia melalui komite nasionalnya.

Untuk mencapai tujuannya ICC telah membuat sejumlah aktivitas. ICC International Court of Arbitration merupakan sebuah badan yang mendengar dan menyelesaikan sengketa pribadi antara partai. Pembuatan kebijakan mereka dan pembelaannya menjadikan pemerintah nasional, sistem PBB dan badan global lainnya mengetahui pemandangan bisnis dunia pada beberapa isu terhangat hari ini.

Hasil yang telah diupayakan oleh badan internasional ini adalah berhasil disusunnya serangkaian aturan mengenai syarat-syarat (dan penjabarannya) bagi perdagangan internasional (international commercial terms atau disingkat dengan "Incoterms").

Dengan kata lain, Incoterms diadakan untuk memberikan suatu perangkat aturan internasional untuk menerjemahkan syaratsyarat perdagangan internasional yang sering kali dipakai. Karena itu, dengan adanya terjemahan yang seragam, maka dapat dihindari timbulnya bermacam-macam penafsiran terhadap syarat-syarat perdagangan internasional.

Dalam perkembangannya Incoterms mengalami beberapa kali perubahan yang dilakukan unrtuk mengikuti perkembangan pada praktik perdagangan internasional. Upaya pertama yang berhasil diperkenalkan dibuat pada tahun 1936 (Incoterms 1936). Sejak itu Incoterms 1936 sudah mengalami 5 
kali penambahan dan perubahan, yaitu pada tahun 1953, 1967, 1976, 1980, dan $1990 .^{2}$

Salah satu latar belakang dilakukannya perubahan pada tahun 1990 adalah karena adanya keinginan untuk mengantisipasi praktik pengiriman data melalui perangkat elektronik (Electro-nic Data Interchange (EDI) yang mengikat. Dalam Incoterms 1990 para pihak dimungkinkan untuk memberikan berbagai dokumen (seperti commercial invoices, dokumen yang dibutuhkan untuk beacukai atau dokumen pembuktian pengiriman barang atau dokumen pengangkutan). Dalam hal demikian itu, masalah yang timbul manakala penjual harus memberikan/menunjukkan suatu dokumen pengangkutan berharga dan khususnya Bill of Lading - B/L atau konosemen yang sering kali digunakan untuk menjual barang sewaktu barang tersebut diangkut. Dalam hal demikian itu, apabila menggunakan sarana EDI sangatlah penting untuk memastikan bahwa ia memiliki kedudukan hukum selayaknya apabila ia telah memilikinya, yaitu telah menerima suatu $\mathrm{B} / \mathrm{L}$ atau konosemen. ${ }^{3}$

Incoterms yang terakhir adalah Incoterms 2010 yang merupakan hasil revisi Kamar Dagang Internasional (International Chamber of Commerce-ICC) tertanggal 1 Januari 2011. ${ }^{4}$

Incotermslahir dari kebiasan-kebiasaan dalam perdagangan internasional dimana kebiasan-kebiasaan yang seragam itu dihimpun oleh ICC dan diberi nama Incoterms.

Karena sifat masih berupa hukum kebiasaan internasional (internasional customary

2 Huala Adolf \& A. Chandrawulan. 1994. Masalah-masalah Hukum Dalam Perdagangan Internasional. Jakarta: Rajawali Pers. hlm 82

3 Ibid

4 Gunawan Widjaja \& Ahmad Yani. Op.cit.hlm 140 law) maka belum mempunyai kekuatan mengikat yang kuat seperti halnya perjanjian internasional (konvensi dan lain-lainnya).

Permasalahan yang sering timbul berkaitan dengan kekaburan hukum (vage norm) berkenaan dengan makna dan ruang lingkup dari Incoterms tersebut. Sebagai contoh istilah dalam perdagangan internasional yang banyak dipergunakan oleh pengusaha ekspor impor di Kalimantan Selatan adalah EXW (Ex Works), FAS (Free Alongside Ship), FOB (Free On Board), CFR (Cost and Freight), CIF (Cost, Insurance, and Freight) dan seterusnya.

Salah satu perdagangan komoditas internasional di Banjarmasin adalah karet. Disamping itu ada juga batubara, minyak sawit (CPO), produk kayu, lampit rotan, dan lain sebagainya. Salah satu perusahaan di Banjarmasin yang bergerak dibidang ekspor karet adalah PT. Insan Bonafide yang menjual crumb rubber ke manca negara. Dalam kontrak-kontrak dagang ekspornya PT. Insan Bonafide juga menggunakan Incoterms.

\section{METODE}

Metode merupakan suatu prosedur atau cara untuk mengetahui sesuatu, yang mempunyai/memiliki langkah-langkah sistematis.

Metode pendekatan yang digunakan dalam karya penulisan jurnal ini adalah Yuridis Normatif yaitu dilaksanakan berdasarkan pada peraturan hukum yang ada. Penulisan dengan pendekatan yuridis normatif dilaksanakan dengan melalui tahapan sebagai berikut:

1. Inventarisasi terhadap peraturan yang mencerminkan kebijaksanaan pemerintah di bidang peraturan perundang-undangan yang berkaitan dengan dokumen perusahaan dan dokumen elektronik. 
2. Menganalisis perundang-undangan dan peraturan-peraturan yang telah diinventarisir tersebut untuk mengetahui sejauh mana peraturan perundangundangan tersebut diatas sinkron baik secara vertikal dan horizontal.

\section{ANALISIS DAN PEMBAHASAN}

\section{A. Pengertian Incoterms}

Incoterms atau International Commercial Terms adalah kumpulan istilah yang dibuat untuk menyamakan pengertian antara penjual dan pembeli dalam perdagangan internasional. Incoterms menjelaskan hak dan kewajiban pembeli dan penjual yang berhubungan dengan pengiriman barang. Hal-hal yang dijelaskan meliputi proses pengiriman barang, penanggung jawab proses ekspor-impor, penanggung biaya yang timbul dan penanggung risiko bila terjadi perubahan kondisi barang yang terjadi akibat proses pengiriman. ${ }^{5}$

Incoterms dalam perjanjian Perdagangan Internasional yang di himpun oleh International Chamber of Commerce-ICC (Kamar Dagang dan Industri) yang berkedudukan di Paris, Perancis. Incoterms lahir dari kebiasaan internasional (international customs) yang merupakan bentuk upaya agar kebiasaan internasional tersebut bisa dijadikan pedoman/ rujukan bagi para pelaku bisnis perdagangan internasional.

Incoterms dikeluarkan oleh Kamar Dagang Internasional atau International Chamber of Commerce (ICC), versi terakhir yang dikeluarkan pada tanggal 1 Januari2011 disebut sebagai Incoterms 2010. Incoterms 2010 dikeluarkan dalam bahasa Inggris sebagai bahasa resmi dan 31 bahasa lain

5 Sudargo Gautama. 1997. Hukum Dagang Internasional. Bandung: Alumni. hlm 59 sebagai terjemahan resmi. Dalam Incoterms 2010 hanya ada 11 istilah yang disederhanakan dari 13 istilah Incoterms 2000, yaitu dengan menambahkan 2 istilah baru dan menggantikan 4 istilah lama. ${ }^{6}$

\section{B. Penggunaan Incoterm dalam Per- janjian Perdagangan Internasional}

The International Chamber of Commerce (ICC) didirikan pada tahun 1919. Badan ini berkedudukan di Paris. Tujuannya pada waktu itu, dan sampai sekarang masih terus berlaku, adalah melayani dunia usaha dengan memajukan perdagangan, penanaman modal, membuka pasar untuk barang dan jasa, serta memajukan aliran modal (to serve world business by promoting trade and investment, open markets for goods and services, and thefree flow of capital). ${ }^{7}$ Selama ini ICC dipandang sebagai corongnya dunia usaha (pengusaha) untuk pertumbuhan ekotidakmi, penciptaan lapangan kerja, dan kemak-muran.

Peran ini sangat penting dalam kaitannya dengan keadaan dunia saat ini. Negaranegara di dunia kerap membuat kebijakan atau keputusan-keputusan yang dapat mempengaruhi perdagangan. Karena itulah, peran atau adanya suatu badan dunia yang menyuarakan para pedagang yang terkena oleh kebijakan atau keputusan (suatu) negara menjadi sangat penting. Mengingat dalam melakukan Bisnisnya suatu membuat kebijakan dan keputusan harus mengingat dasar atau norma hukum Nasional masing-masing.

Untuk itu, ICC memiliki akses langsung kepada pemerintah negara-negara di dunia

6 Soedjono Dirdjosisworo. 2006. Pengantar Hukum Dagang Internasional. Refika Aditama, hlm 38

7 Huala Adolf. Hukum Perdagangan Internasional. Jakarta: PT Raja Grafindo Jakarta. 2005. hlm 2425. 
melalui national committee ICC (KADIN Nasional) yang terdapat hampir di setiap negara di dunia.

Peran penting lain ICC adalah sebagai badan dalam membuat kebijakan-kebijakan atau aturan-aturan yang dapat memfasilitasi perdagangan internasional. Peran lain yang juga cukup penting adalah sebagai forum penyelesaian sengketa khususnya melalui arbitrase, sebagai forum untuk menyebarluaskan informasi dan kebijakan serta aturan-aturan hukum dagang internasional di antara pengusaha-pengusaha di dunia; dan memberikan pelatihan-pelatihan dan teknik-teknik dalam merancang kontrak serta keahlian-keahlian praktis lainnya dalam perdagangan internasional.

ICC tidak berupaya menciptakan unifikasi hukum. Kebijakan yang ditempuhnya adalah memberikan aturan-aturan dan standarstandar (Rules and Standart) di bidang hukum perdagangan internasional. Kedua bentuk aturan ini sifatnya tidak mengikat.

Hal ini sebenarnya tidak terlepas dari pendirian ICC bahwa dunia usaha sebaiknya tidak atau dipengaruhi sedikit mungkin oleh campur tangan penguasa (pemerintah). ICC karenanya tidak mau menjadi penguasa seperti itu. Ia berpendirian, biarlah dunia usaha saja yang mengatur atau membuat aturan bagi mereka sendiri.

Dana aturan-aturan yang sifatnya atau yang datang dari luar, termasuk at-uran-aturan yang dibuat ICC, haruslah bersfiat sukarelah saja. Namun demikian aturan-aturan ICC (termasuk standar-standar ICC) ini memiliki pengaruh yang cukup tinggi. Bahkan beberapa aturan (Rules)nya telah diikuti dengan sukarela dan seksama oleh para pelaku dagang, seperti misalnya perbankan.
Bahkan standar-standar yang dikeluarkan oleh ICC telah banyak dimasukkan ke dalam kontrak-kontrak dagang yang dibuat oleh para pelaku bisnis.

Hasil yang telah diupayakan oleh badan internasional ini adalah berhasil disusunnya serangkaian aturan mengenai syarat-syarat (dan penjabarannya) bagi perdagangan internasional (international commercial terms atau disingkat dengan "Incoterms").

Sebagaimana telah kita ketahui bersama, ekonomi global telah memberikan akses pasar yang lebih luas bagi dunia usaha dari sebelumnya di seluruh dunia. Barang barang dijual di banyak Negara,dalam kuantitas yang lebih besar dan dalam jenis yang lebih banyak. Tetapi sebagaimana perkembangan perdagangan internasional yang semakin besar dan kompleks ini, kemungkinan terjadi salah pengertian dan perselisihan akan semakin besar jika kontrak penjualan tidak disusun dengan baik.

Incoterms yang merupakan aturan resmi ICC sebagai interprestasi dari syarat-syarat perdagangan, memudah-kan dalam transaksi perdagangan internasional. Penggunaan Incoterms 2010 dalam kontrak penjualan akan memberikan batasan-batasan bagi pihak-pihak tentang kewajiban-kewajiban dan mengurangi resiko komplikasi hukum.

Sejak pertama kali lahirnya Incoterms oleh ICC pada tahun 1936,syarat-syarat perdagangan ini telah secara teratur diperbaharui untuk mengikuti perkembangan perdagangan internasional. Incoterms digunakan untuk mengantisipasi perkembangan terakhir penyebaran zona perdagngan bebas, peningkatan penggunaan komunikasi elektronik dalam transaksi bisnis, dan perubahan tata cara transportasi. Incoterms 2010 menawarkan suatu presentasi yang lebih sederhana dan lebih 
jelas dari 11 definisi/istilah dalam Incoterm, yang mana semuanya telah di revisi.

Adanya keahlian yang luas dari Commision on International practice dari ICC yang diambil dari semua bagian dunia dan semua sector perdangan, menjamin bahwa Incoterms 2010 menjawab kebutuhan dunia usaha di mana saja. Dengan adanya Incoterms ini untuk menyediakan seperangkat peraturan internasional sebagai interpretasi sebagian besar syarat perdagangan yang lazim dipakai dalam perdagangan luar negeri.Dengan demikian ketidakpastian dari berbagai pengertian mengenai syarat perdagngan itu yang terdapat di berbagai Negara dapat dihindari atau setidak-tidaknya dapat ditekan hingga batas yang wajar.

Seringkali pihak-pihak yang terlibat dalam suatu kontrak tidak menyadari adanya perbedaan dalam praktik perdagngan di berbagai Negara.Hal ini dapat menimbulkan salah pengertian, perselisihan dan bahkan menjadi urusan pengadilan, yang pada akhirnya da-pat membuang-buang waktu dan uang. Untuk menghindari hal ini maka Kamar Dagang Internasional, untuk pertama kalinya tahun 1936 telah menerbitkan seperangkat peraturan internasional tentang pengertian/ interpretasi syarat perdagangan. Peraturan ini di kenal sebagai "Incoterms1936". Perubahan dan tambahan telah di lakukan berturut-turut tahun 1953,1967,1976,1980,1990,2000 dan sekarang tahun 2010 dalam rangka untuk menyesuaikan peraturan peraturan ini dengan perkembangan yang terjadi dalam praktik perdagangan internasional.

Ruang lingkup Incoterms di batasi pada hal-hal yang berhubungan dengan hak dan kewajiban dari pihak-pihak dalam kontrak

$8 \quad$ Ibid penjualan mengenai pengiriman dari barangbarang yang di jual (yang berwujud/tangibles, tidak termasuk "yang tidak terwujud/ intangibles" seperti software computer).

Ada dua kesalahpahaman (misconception) yang sering muncul tentang Incoterms. Pertama, Incoterms seringkali di salahartikan sebagai aplikasi dari kontrak pengangkutan (contract of carriage) dari kontrak penjualan (contract of sale).Kedua,seringkali terjadi salah anggapan bahwa incoterm menyediakan untuk semua kewajiban (duties) di mana pihak-pihak mungkin mengharapkan untuk memasukannya dalam suatu kontrak penjualan

Sebagaimana selalu di garisbawahi oleh ICC, Incoterms hanya berkaitan dengan hubungan antara penjual dan pembeli di bawah kontrak penjualan, dan lebih jauh, hanya "do so in some very distinct respect" 9

Walaupun Incoterms sangant penting bagi eksportir dan importer untuk mempertimbangkan hubungan yang praktis antara beragam kontrak yang di perlukan untuk menyelenggarakan transaksi penjualan internasional dimana tidak hanya kontrak penjualan yang diperlukan, tetapi juga kontrak pengangkutan, asuransi dan pembiayaan Incoterms hanya berkaitan dengan salah satu dari kontrak tersebut yaitu, kontrak penjualan.

Meskipun demikian, persetujuan pihakpihak untuk menggunakan incoterm juga akan memiliki implikasi-implikasi bagi kontrak lainnya.

Secara umum, Incoterms tidak berkaitan dengan konsekuensi-konsekuensi dari pelanggaran kontrak dan pengecualian-penge-

9 Gunawan Widjaja \& Ahmad Yani, Transaksi Bisnis Internasional (Ekspor-Impor \&Imbal Beli), rajawali pers, jakarta, 2000, hlm 143. 
cualian dari kewajiban yang belum terbayar pada berbagai kesukaran.

Incoterms selalu di tujukan untuk di gunakan bagi barang-barang yang di jual dan diangkut melewati batas-batas suatu Negara karenanya disebut International Commercial Terms. Namun demikian, dalam praktiknya kadang-kadang juga di gunakan dalam kontrak perdagangan barang-barang dalam pasar domestic. Kalau ini terjadi maka ada klausulaklausula dan ketetapan lain yang berkaitan dengan ekspor dan impor dalam Incoterms menjadi tidak berguna.

Dengan kata lain, Incoterms diadakan untuk memberikan suatu perangkat aturan internasional untuk menerjemahkan syaratsyarat perdagangan internasional yang sering kali dipakai. Karena itu, dengan adanya terjemahan yang seragam, maka dapat dihindari timbulnya bermacam-macam penafsiran terhadap syarat-syarat perdagangan internasional.

Incoterms atau syarat perdagangan atau terms of trade merupakan kelengkapan dari "Sales Contract" yang mengantur tentang hak dan kewajiban antara penjual dan pembeli yangmenyangkut :

1. Penyerahan barang dari penjual kepada Pembeli

2. Pembagian resiko antara penjual dan pembeli.

3. Tanggung jawab dalam perolehan ijin ekspor-impor.

Incoterms sudah diakui oleh Pemerintah, Otoritas Hukum dan para Pelaku Perdagangan hampir disemua negara di dunia sebagai rujukan utama bagi penafsiran berbagai istilah yang biasadigunakan dalam transaksi komersial di dunia internasional. Hal tersebut akan mengurangi resiko kesalahan tafsir bagi antar pelaku perdagangan international, karena sudah adanya kesepakatan yang diketahui bersama.

Perlu di tekan kan bahwa ruang lingkup dari Incoterms ini hanya terbatas pada materi yang berhubungan dengan kewajiban yang berhubungan dengan kewajiban pihak-pihak yang terkait dan kontrak jual beli yang berkenaan dengan penyerahan barang-barang yang diperdagangkan dalam pengertian barang yang dapat diperdagangkan,tidak termasuk barang yang tak dapat diraba seperti perangkat lunak komputer.

1. Terlihat adanya dua buah kesepahaman tentang Incoterms yang sangat lazim: Incoterms sering disalah pahami sebagai aplikasi kontrak pengangkutan melebihi dari kontrak jualbeli.

2. Incoterms kadang kala secara keliru dianggap menyediakan untuk semua pihak kewajiban-kewajiban yang pihak-pihak terkait mengingini untuk dimasukan didalam kontrak jualbeli.

ICC Indonesia berpendapat bahwa halhal yang diatur dalam Incoterms akan sangat mementukankeberhasilan dan profitabilitas perusahaan yang bergerak dalam perdagangan.

Oleh karena itudunia usaha Indonesia utamanya para eksportir, importer, perbankan yang terkait dan parapengusaha angkutan (lautudaradarat) perlu meningkatkan awardness tentang keberadaanIncoterms ini.

Untuk memperlancar perdagangan maka yang harus dipahami sebelum melakukan perdagangan adalah :

1. Kedua belah pihak harus sepakat dan memahami kontrak berdasarkan Incoterms.

2. Memilik term yang sesuai dan cocok untuk kedua belah pihak 
3. Mencantumkan dengan jelas, lokasi tempat/pelabuhan/terminal yang menjadi titik asal dantitik tujuan.

4. Memahami bahwa kontrak dagang adalah sangat rumit.

Sementara itu adalah penting sekali bagi eksportir dan importer untuk mempertimbangkan hubungan praktis antara berbagai kontrak dalam mengaktualisasikan suatu kontrak jual beli internasional,dimana tidak hanya kontrak jual beli yang dibutuhkan tetapi juga kontrak angkutan, asuransi, pembiayaan, sedangkan Incoterms hanya berhubungan dengan salah satu saja dari ketiga jenis kontrak itu,yakni dengan kontrak jual beli saja,Namun begitu pihak-pihak yang terlibat dengan perjanjian itu yang memakai salah satu syarat Incoterms ini mempunyai dampak juga terhadap kontrak-kontrak lainya.

Incoterms ini berurusan dengan sejumlah kewajiban-kewajiban tertentu yang diharuskan kepada pihak-pihak terkait seperti kewajiban penjual untuk menempatkan barang-barang kedalam kewenangan pembeli atau menyerahkannya untuk diangkut atau menyerahkannya ditempat tujuan. Juga berhubungan dengan pembagian resiko antar pihak-pihak terkait dalam kasus-kasus itu.

Incoterms juga berurusan dengan masalah penyelesaian ijin ekspor-import barang, pengepakan,kewajiban pembeli untuk menerima penyerahan barang dan kewajiban membuktikan bahwa tugas telah dilaksanakan. Incoterms bukan sebagai penganti syaratsyarat kontrak kontrak yang dibutu-hkan suatu kontrak jual beli yang mencantumkan pelarangan yang jelas.

Incoterms tidak berhubungan dengan pembatalan suatu kontrak, Incoterms selalu diutamakan untuk dipakai untuk barang- barang yang dijual dengan penyerahan melewati batas Negara dan menjadi syarat penting perdagangan internasional,tapi kadang juga dipakai untuk perdagangan dalam negeri sehingga secara otomatis pasal-pasal A2 dan B2 dan keterangan lain yang menyangkut masalah eksport-import dengan sendirinya menjadi mubazir.

Dalam perkembangannya Incoterms mengalami beberapa kali perubahan yang dilakukan untuk mengikuti perkembangan pada praktik perdagangan internasional. Upaya pertama yang berhasil diperkenalkan dibuat pada tahun 1936 (Incoterms 1936). Sejak itu Incoterms 1936 sudah mengalami 5 kali penambahan dan perubahan, yaitu pada tahun 1953, 1967, 1976, 1980, dan 1990. ${ }^{10}$

Alasan utama dilakukannya revisi Incoterms adalah didorong kebutuhan untuk menyesuaikan praktik-praktik perdagangan yang kontemporer. Sebagai misal, dalam revisi tahun 1980, terminology Free Carrier (sekarang FCA) diperkenalkan dalam rangka mengaitkan dengan kasus yang sering terjadi di mana reception point dalam perdagangan maritim tidak lagi FOB-point (Free On Board point) tetapi suatu titik di darat sebelum pemuatan pada kapal, di mana barang-barang dimuat dalam container untuk transportasi air berikutnya atau transportasi multimodal.

Salah satu latar belakang dilakukannya perubahan pada tahun 1990 adalah karena adanya keinginan untuk mengantisipasi praktik pengiriman data melalui perangkat elektronik (Electronic Data Interchange (EDI) yang mengikat. Dalam Incoterms 1990 para pihak dimungkinkan untuk memberikan berbagai

10 Huala Adolf \& A. Chandrawulan. Masalahmasalah Hukum Dalam Perdagangan Internasional. Jakarta: Rajawali Pers. 1994. hlm 82. 
dokumen (seperti commercial invoices, dokumen yang dibutuhkan untuk beacukai atau dokumen pembuktian pengiriman barang atau dokumen pengangkutan). Dalam hal demikian itu, masalah yang timbul manakala penjual harus memberikan/menunjukkan suatu dokumen pengangkutan berharga dan khususnya Bill of Lading $B / L$ atau kotidaksemen yang sering kali digunakan untuk menjual barang sewaktu barang tersebut diangkut.

Dalam hal demikian itu, apabila menggunakan sarana EDI sangatlah penting untuk memastikan bahwa ia memiliki kedudukan hukum selayaknya apabila ia telah memilikinya, yaitu telah menerima suatu $\mathrm{B} / \mathrm{L}$ atau kon-osemen. ${ }^{11}$

Karena ada perubahan Incoterms dari waktu ke waktu, adalah penting untuk menjamin bahwa jika para pihak bermaksud untuk menggunakan incoterm dalam kontrak penjualan, suatu referensi yang cepat selalu di buat pada versi terbaru dari Incoterms. Ini dapat memudahkan jika suatu referensi telah di buat untuk versi sebelumnya dalam formulir kontrak standar atau dalam formulir pesanan yang di gunakan para pedagang. Kegagalan dalam merujuk kepada versi terbaru mungkin menimbulkan perselisihan apakah para pihak bermaksud menggunakan versi itu atau versi sebelumnya sebagai bagian dari kontrak mereka. Para pedagang yang bermaksud menggunakan Incoterms 2010 harus menyatakan secara spesifik dan jelas dalam kontrak mereka tunduk pada "Incoterms 2010".-

Incoterms yang terakhir adalah Incoterms 2010 yang merupakan hasil revisi Kamar

11 Ibid
Dagang Internasional (International Chamber of Commerce-ICC) tertanggal 1 Januari 2011 . $^{12}$

Incoterms memiliki fungsi untuk dapat menjelaskan hak dan kewajiban pembeli dan penjual yang berhubungan dengan pengiriman barang, meliputi proses pengiriman barang, penanggung jawab proses ekspor-impor, penanggung biaya yang timbul serta penanggung risiko bila terjadi perubahan kondisi barang yang terjadi akibat proses pengiriman.

Pemahaman yang baik dan menyuluruh atas Incoterms akan mengurangi risiko dan biaya-biaya tak terduga bagi pengusaha yang melakukan perdagangan internasional. Potensi terjadinya permasalahan dalam bermacam hal dalam perdagangan internasional akan berkurang, dengan demikian daya saing eksportir dan importir Indonesia pada gilirannya akan meningkat. Oleh karena itu pemahaman akan Incoterms kepada seluruh proses perdagangan sangatlah penting.

Karena sifat masih berupa hukum kebiasaan internasional (internasional customary law) maka belum mempunyai kekuatan mengikat yang kuat seperti halnya perjanjian internasional (konvensi dan lainlainnya).

\section{Penggunaan Incoterms Pada Perjanjian Perdagangan Internasional di PT. Insan Bonafide di Banjarmasin}

Secara global, bentuk atau wujud hukum pada umumnya terbagi atas dua, yakni, hukum tertulis dan hukum tidak tertulis. Demikian Pula halnya dengan hukum internasional. Hukum internasional dapat dikenali bentuk atau wujudnya dalam bentuk hukum internasional tertulis dan hukum internasional tak tertulis atau yang disebut juga dengan hukum kebiasaan internasional (customary law).

12 Gunawan Widjaja \& Ahmad Yani. Op.cit.hlm 140 
Sumber hukum dipakai pertama sekali pada arti dasar berlakunya hukum. Dalam hal ini yang dipersoalkan adalah apa sebabnya suatu hukum mengikat, yakni sebagai sumber hukum material yang menerangkan apa yang menjadi hakikat dasar kekuatan mengikatnya hukum internasional. ${ }^{13}$

Sumber hukum internasional dapat diartikan sebagai:

a. Dasar kekuatan mengikatnya hukum internasional;

b. Metode penciptaan hukum internasional

c. Tempat diketemukannya ketentuanketentuan hukum internasional yang dapat diterapkan pada suatu persoalan konkrit. ${ }^{14}$

Sumber hukum ada 2 jenis yakni:

a. Sumber hukum materil: dapat didifenisikan sebagai bahan-bahan aktual yang dipergunakan oleh seorang ahli hukum internasional untuk menentukan kaidah hukum yang berlaku terhadap suatu peristiwa atau situasi tertentu. ${ }^{15}$

b. Sumber hukum Formal: merujuk kepada bukti-bukti baik secara umum maupun khusus yang menunjukkan bahwa hukum tertentu telah diterapkan dalam suatu kasus tertentu. Dari sebuah hukum materiil inilah isi dari sebuah hukum bisa ditemukan. ${ }^{16}$

Dalam hukum tertulis, ada dua tempat yang mencantumkan secara tertulis sumber

13 Mochtar Kusumaatmadja, Etty R. Agoes, Pengantar Hukum Internasional, Cetakan pertama. Bandung. P.T. Alumni. 2003. hlm. 113.

14 Yordan gunawan, "Pengantar Hukum Internasional”, http://telagahati.wordpress.com. Diakses Senin, 20 oktober 2015

15 J. G. starke, Op. Cit. hlm. 42

16 Benny setianto, "Sumber hukum internasional", http://bennysetianto.blogspot.com. hukum internasional dalam arti formal yakni pasal 7 Konvensi Den Haag XII 1907 tentang pembentukan Mahkamah Internasional Perampasan Kapal di Laut (International Prize Court) dan dalam pasal 38 Piagam Mahkamah Internasional Permanen tahun 1920 yang kini tercantum dalam Pasal 38 Piagam Mahkamah Internasional tahun 1945. Namun keberadaan Mahkamah Internasional Perampasan Kapal di Laut tidak pernah terbentuk dikarenakan jumlah ratifikasi yang diperlukan tidak tercapai, sehingga sumber hukum internasional yang dipakai pada masa sekarang hanya pasal 38 Piagam Mahkamah Internasional.$^{17}$

Pasal 38 ayat (1) dari Piagam Mahkamah Internasional (International Court of Justice) menyatakan bahwa Mahkamah yang memiliki fungsi untuk memutus sesuai dengan hukum internasional yang diajukan kepadanya, akan memberlakukan sumber-sumber hukum sebagai berikut:

a. Konvensi internasional, baik umum maupun khusus, yang membentuk aturanaturan yang diakui secara tegas oleh negara-negara yang bersengketa;

b. Kebiasaan internasional, sebagai bukti praktek umum yang diterima sebagai hukum;

c. Asas-asas hukum umum yang diterima oleh bangsa-bangsa yang beradab;

d. Tunduk kepada ketentuan pasal 59, putusan pengadilan dan ajaran para ahli yang sangat memenuhi syarat dari berbagai negara seba-gai sarana pelengkap bagi penent-uan aturan hukum.

Urutan penyebutan sumber hukum dalam pasal 38 ayat (1) Piagam Mahkamah Internasional tidak menunjukkan urutan pentingnya masing-masing sumber hukum

17 Mochtar Kusuma Atmadja, Op. Cit. hlm. 114 
itu sebagai sumber hukum formal, karena hal ini sama sekali tidak diatur oleh pasal 38. Pasal 38 mengklasifikasikan sumber hukum internassional formal kedalam 2 bagian yaitu sumber hukum pokok bagi pembentukan hukum internasional dibagian a sampai dengan bagian c, dan sumber hukum tambahan atau pelengkap pada bagian d. Hal ini berarti bahwa sarana-sarana utama (a-c) diperlukan, dan bahwa sarana pelengkap (d) hanya memiliki efek yang memenuhi kualifikasi dan atau efek penjelasan.

Dalam hubungan ini, bentuk atau perwujudan dari hukum internasional, baik yang berbentuk tertulis maupun tidak tertulis dihubungkan dengan ruang lingkup berlakunya, baik ruang lingkup subyek hukumnya maupun kawasan berlakunya. Jika dipandang secara menyeluruh, maka hukum internasional baik yang berbentuk tertulis seperti perjanjian-perjanjian internasional maupun hukum kebiasaan internasional, dapat dibedakan dalam tiga kelompok bentuk perwujudannya, yaitu hukum internasional umum atau universal atau global (general, universal, or global international law), hukum internasional regional atau kawasan (regional international law), dan hukum internasional khusus (special international law).

Sumber hukum perdagangan internasional yang sebenarnya merupakan sumber utama dan terpenting adalah perjanjian atau kontrak yang dibuat oleh para pedagang sendiri. Seperti kita dapat pahami, kontrak tersebut adalah undang-undang bagi para pihak yang membuatnya. ${ }^{18}$

18 Cf., Alinea pasal 1 Pasal 1338 KUH Perdata:"Semua perjanjian yang dibuat secara sah berlaku sebagai undang-undang bagi mereka yang membuatnya."
Dapat pula kita sadari bahwa para pelaku perdagangan (pedagang) atau stakeholders dalam hukum perdagangan internasional, ketika melakukan transaksi perdagangan internasional, mereka menuangkannya dalam perjanjian-perjanjian tertulis(kontrak). Oleh karena itu, kontrak sangat esensial.

Dengan demikian, kontrak berperan sebagai sumber hukum yang perlu dan terlebih dahulu mereka jadikanacuan dalam perdagangan internasional.

Dalam hukum kontrak, kita mengenal penghormatan dan pengakuan terhadap prinsip konsensus dan kebebasan para pihak (party autonomy). Syarat-syarat perdagangan dan hak serta kewajiban para pihak seluruhnya diserahkan kepada pihak dan hukum menghormati kesepakatan ini yang tertuang dalam perjanjian.

Meskipun kebebasan para pihak sangatlah esensial, namun kebebasan tersebut ada batasnya. Ia tunduk pada berbagai pembatasan yang melingkupinya. Pertama, pembatasan yang utama adalah bahwa kebebasan tersebut tidak boleh bertentangan dengan undangundang, dan dalam taraf tertentu, dengan ketertiban umum, kesusilaan, dan kesopanan.

Pembatasan kedua, adalah status dari kontrak itu sendiri. Kontrak dalam perdagangan internasional tidak lain adalah kontrak nasional yang ada unsur asingnya. ${ }^{19}$ Artinya, kontrak tersebut, meskipun di bidang perdagangan internasional, paling tidak tunduk dan di batasi oleh hukum nasional (suatu negara tertentu).

Ketiga, menurut Sanson, pembatasan lain yang juga penting dan mengikat para pihak adalah kesepakatan-kesepakatan

19 Sudargo Gautama. Kontrak Dagang Internasional. Bandung: Alumni,1976 
atau "kebiasaan" dagang yang sebelumnya dilakukan oleh para pihak yang bersangkutan. Daya mengikat kesepakatan-kesepakatan sebelumnya ini meskipun tidak tertulis, tetapi mengikat ini.

"In addition to the contractual terms agreed by the parties, the course of past dealings between traders may result in terms becoming part of an agreement between them. These past dealings, or trade 'usages' between the parties, may apply to the contractual relationship despite their not being incorporated into it in written form, 20

Menurut Peter Mahmud Marzuki, ${ }^{21}$ aturan hukum yang menguasai kontrak sebenarnya penjelmaan dari dasar-dasar filosofis yang terdapat pada azas-azas hukum secara umum. Azas hukum merupakan sumber bagi sistem hukum yang memberi inspirasi mengenai nilai-nilai etis, moral dan sosial masyarakat.

M.Isnaeni ${ }^{22}$ menyebut beberapa azas sebagai tiang penyangga Hukum Kontrak, yaitu azas kebebasan berkontrak yang berdiri sejajar dengan azas-azas lain berdasar proporsi yang berimbang, yaitu :
a. azas pacta sunt servanda,
b. azas kesederajatan,
c. azas privity of contract
d. azas konsensualisme, dan
e. azas itikad baik

Azas kebebasan berkontrak merupakan azas yang menduduki posisi sentral didalam hukum kontrak, meskipun azas ini tidak dituangkan menjadi aturan hukum namun

20 Michelle Sanson, op.cit., hlm. 7.

21 Peter Mahmud Marzuki. Op.Cit. hlm.196.

22 M. Isnaeni. "Hukum perikatan Dalam Era Perdagangan Bebas" airlangga. Surabaya. 2006 hlm 5 . mempunyai pengaruh yang sangat kuat dalam hubungan kontraktual para pihak.

Dengan demikian menurut azas kebebasan berkontrak, seseorang pada umumnya mempunyai pilihan bebas untuk mengadakan perjanjian. $^{23}$

Di dalam azas ini terkandung suatu pandangan bahwa orang bebas untuk melakukan atau tidak melakukan perjanjian, bebas dengan siapa ia mengadakan perjanjian, bebas tentang apa yang diperjanjikan dan bebas menetap-kan syarat-syarat perjanjian ${ }^{24}$.

Di dalam Incotermsada beberapa hal hal yang di jelaskan meliputi proses pengiriman barang,penanggung jawab ekspor-impor, penanggung biaya yang timbul dan penanggung resiko bila terjadi perubahan kondisi barang yang terjadi akibat proses pengiriman. Incoterms atau syarat perdagangan atau terms of trade merupakan kelengkapan dari "Sales Contract" yang mengatur tentang hak dan kewajiban penjual dan pembeli yang menyangkut penyerahan barang dari penjual kepada pembeli, pembagian resiko antara penjual dan pembeli serta tanggung jawab dalam perolehan ijin ekspor-impor.

Perusahaan lokal swasta nasional yang bergerak di bidang industri pengolahan hasil perkebunan karet yang memiliki hasil produksi standart internasional.

Secara garis besar usaha yang dijalankan berupa pengolahan bahan baku disortir mulai dari penyadapan getah pohon karet,dilanjutkan proses produksi dari bahan mentah karet sampai menjadi bahan baku produk yang berbahan dasarkan karet, selanjutnya dikemas dan siap di ekspor. Produk yang dihasilkan oleh PT. Insan Bonafide adalah karet bongkah

23 Peter Mahmud Marzuki. Op.Cit. hlm.31.

24 Loc. Cit. 
atau dikenal juga dengan block rubber (SIR 10 \& SIR 20) yang di kirim ke berbagai negara seperti Jepang, Korea, Perancis, Italia, Afrika dll dengan pelanggan utamanya adalah:
a. SMPT,
b. Brigestone,
c. Goodyear,
d. Weber \& Schaer.

Dalam proses pengiriman ke mancanegara atau ekspor perusahaan ini mengikuti rules yang sudah ada yang telah di tetapkan menggunakan Incoterm 2010.

Dalam praktik yang dialami oleh PT. Insan Bonafide ketentuan-ketentuan Incoterms tersebut, yakni FAS (Free Alongside Ship), FOB (Free On Board), CFR (Cost and Freight), dan CIF (Cost, Insurance, and Freight)ma-sih menimbulkan permasalahan dalam aplikasi/ penerapannya di lapangan karena masih terdapat kekaburan hukum (vage normen) mengenai ruang lingkup dan batas-batas tanggung jawab masing-masing pihak antara penjual (eks-portir) dan importir, contohnya berka-itan dengan apa saja yang masuk dalam elemen biaya-biaya (costs), seberapa luas risiko asuransi yang dijamin (apakah All Risks atau Partial Risks/ Total Loss Only).

\section{PENUTUP}

Incoterms dalam perjanjian Perdagangan Internasional yang di himpun oleh International Chamber of Commerce-ICC (Kamar Dagang dan Industri) yang berkedudukan di Paris, Perancis. Incoterms lahir dari kebiasaan internasional (international customs) yang merupakan bentuk upaya agar kebiasaan internasional tersebut bisa dijadikan pedoman/ rujukan bagi para pelaku bisnis perdagangan internasional.Agar para pihak khususnya pengguna incoterms dapat terhindar dari berbagai permasalahan,para pihak di tuntut untuk lebih jeli dalam memilih terminology di incoterms dan menambahkan klausul-klausul tertentu yang dianggap masih kurang jelas aturannya di dalam incoterm telah agar tidak terjadi sengketa dalam proses pengiriman.

Hendaknya ketentuan-ketentuan yang terdapat dalam Incoterms seperti FAS (Free Alongside Ship), FOB (Free On Board), CFR (Cost and Freight), dan CIF (Cost, Insurance, and Freight) mengatur secara jelas, tegas, dan lengkap mengenai hak-hak dan kewajibankewajiban dari pihak dalam perdagangan internasional, yaitu penjual (eksportir) dan pembeli (importir).

\section{DAFTAR PUSTAKA}

\section{Perundang-undangan}

Kitab Undang-undang Hukum Dagang

Kitab Undang-undang Hukum Perdata

Undang-undang No. 1 Tahun 1987 tentang Kamar Dagang dan Industri.

Undang-undang No. 7 Tahun 2014 tentang Perdagangan.

Incoterms 2010

\section{Buku-Buku}

Adolf, Huala \& A. Chandrawulan. 1994. Masalah-masalah Hukum Dalam Perdagangan Internasional. Jakarta: Rajawali Pers.

Adolf, Huala. 2005. Hukum Perdaga-ngan Internasional. Jakarta: Ra-jawali Pers.

Dirdjosisworo, Soedjono. 2006. Pengantar Hukum Dagang Internasional. Refika Aditama.

Gautama, Sudargo. 1997. Hukum Dagang Internasional. Bandung: Alumni. 
Isnaeni, M. 2006. Hukum perikatan Dalam Bisnis. Jakarta: Rajawali Pers.

Era Perdagangan Bebas. . Surabaya:

Airlangga

Kusumaatmadja, Mochtar. 1976. Pen-gantar Hukum Internasional. Buku 1. Bandung: Bina Cipta.

Starke J.G.2006. Pengantar Hukum I-nterasional. Jilid 1, jakarta : Sinar Grafika.

Widjaja, Gunawan \& Ahmad Yani. 2001. Transaksi Bisnis Intern-asional (EksporImpor \& Imbal Beli. Seri Hukum

Anwar, Chairul. 2001 .Hukum Perda-gangan Internasional .Jakarta: Novindo Pustaka Mandiri.

Hata. 2006 Perdagangan Internasional dalam Sistem GATT dan WTO. Aspek Hukum dan Non Hukum. Bandung : Refika Aditama.

Hutauruk, Alfred. 1983, Sistem dan Pelaksanaan Ekspor Impor dan Lalu Lintas Devisa di Indonesia. Jakarta: Erlangga 